The Agriculturists 14(2):124-129(2016) ISSN 2304-7321 (Online), ISSN 1729-5211 (Print)

A Scientific Journal of Krishi Foundation

Indexed Journal

Impact Factor: 0.402 (GIF, 2014)

Short Communication

\title{
Effect of Indole Butyric Acid on Raising Plants from Stem Cuttings of Tea (Camellia sinensis L.) in The Nursery
}

\author{
Mohammed Enamul Hoque* \\ Bangladesh Tea Board, Regional Office, Soalok, Bandarban, Bangladesh \\ *Corresponding author and Email: enam_btb@yahoo.com
}

Received: 31 July 2016

Accepted: 12 December 2016

\begin{abstract}
A field experiment was conducted at the central nursery of tea extension center of Bangladesh Tea Board in Bandarban during September to November, 2015 to determine the precise concentration of Indole Butyric Acid (IBA) on propagation through stem cuttings of tea. The experiment was laid out in a randomized block design with four treatments of IBA concentrations: 0 ppm (Control), $2000 \mathrm{ppm}$, $4000 \mathrm{ppm}$ and $6000 \mathrm{ppm}$ and each treatment was replicated four times. Basal part of tea (BT-2 variety) cuttings were dipped in different IBA concentrations for five seconds. Then these cuttings were dibbled into prepared soil mixture as rooting media. Cuttings were exposed to the rooting media for 90 days and then they all were removed carefully to assess the variation of establishment of cuttings. IBA treated cuttings showed better effect on the rooting rate, root length, root number, shoot length and survival rate compared to the control. It was noted that cuttings treated with $4000 \mathrm{ppm}$ IBA produced the highest rooting rate $79.85 \%$, the highest survival rate $57.60 \%$ and the highest root length of 4.85 $\mathrm{cm}$ followed by treatment $6000 \mathrm{ppm}$ IBA. In case of all parameters, effects of the treatments $4000 \mathrm{ppm}$ and $6000 \mathrm{ppm}$ of IBA were statistically similar. Positive and strong correlation was observed both in rooting rate versus survival rate and root length versus shoot length in IBA treated cuttings. Thus, IBA at $4000 \mathrm{ppm}$ concentration was recommended for establishment of stem cuttings of tea (BT-2 variety) in the nursery.
\end{abstract}

Keywords: Tea, Stem cuttings, IBA concentration.

Tea (Camellia sinensis L.) is a self-sterile, cross pollinated perennial crop. Propagation through true seeds do not produce true to type plants and therefore vegetative propagation is the only method of production of true to type plants. Cultivated tea is conventionally propagated by single leaf node cutting. The most desired and important factor in the selection of tea mother bush for vegetative propagation is its early rooting ability. Plant growth regulator is an important factor to determine the plant growth and their development and the scientists greatly contribute in horticulture and the practical gardener with plant growth substances to enhance the rooting of cuttings (Prockter, 1975). Establishment and growth rate of cuttings depend upon various factors such as age and mother plants vigor, woodiness and location of the stem cutting, growth regulator, environment, nutrient and genetic factors related to the genus or species of interest (Abou-Rawash et al., 1998). There are some interesting reports on the 
response of cuttings of tea those were pre-treated with plant growth regulators.

Export of tea has been declining due to lack of exportable surplus in Bangladesh. Statistics appears that few years earlier tea was a prominent export item in our country but recently it is an import item of commodities due to tea consumption increases @ 3.23\%, whereas tea production increases@ $2 \%$ per year for the last 5 years (DPP, 2016). Therefore new extension of tea is very crucial for the growth of production to mitigate current demand as well as to save economy. Due to the stagnant condition of expansion of tea in the prevailing tea estates, Bangladesh tea board and eminent tea professionals of the country discover the potential scope of smallholding tea cultivation over the country through a feasibility study during 2002. The report reveals that 46875 hectares of land in Chittagong Hill Tracts are suitable for smallholding tea cultivation which is more than the tea planting area of estate sector in the country (PMTC, 2002). Regarding the immense scope of extension of small holding tea cultivation as a new avenue for tea, It necessitate the raising of huge amount of tea planting materials locally over the year for rapid extension of tea cultivation. But year round raising of tea clone in Chittagong Hill Tracts is a major problem due to high mortality rate of tea cutting in the nursery in winter except rainy season which hampering the progress of tea cultivation extension.

Considering the problem of poor establishment of tea stem cuttings in the nursery the present study was carried out to determine the effect of IBA and to select the optimal concentration of IBA application on tea stem cuttings for raising tea plants in the nursery.

The experiment was carried out at the central nursery of tea extension center of Bangladesh Tea Board, Bandarban district during September to December of 2015. Sandy loam soil was collected and mixed with decomposed cow dung (one-fourth of total soil), nematicide and TSP before 20 days of cuttings dibbling. Thereafter the mixture was sieved through mesh net $(8 \mathrm{No}$.) for the preparation of rooting materials. The $5 \times 7$ inches sized polythene sleeves were filled with soil mixture and arranged on bed under agro shed net tunnel which protect direct sun light. Suitable shoots were collected from healthy tea bushes of clone BT-2 variety from different garden of Bandarban. Uniform single node cuttings of 2.5-3.0 cm long from new shoots were used for the experiment. Typically three, sometimes four cuttings were made from each shoot, depending on the length of the internodes of the shoot. Prepared cutting were soaked in a disinfecting solution of fungicide Cupravit for 2 3 minutes just prior to application of growth regulators. Indole Butyric Acid (IBA) at the rate of $0,2000,4000,6000 \mathrm{ppm}$ were applied as treatments for experiment. The solutions were prepared by dissolving $0,200,400,600 \mathrm{mg}$, respectively of IBA pure crystal in drops of (1.N) $\mathrm{NaOH}$ and diluted with water to make 100 $\mathrm{mL}$ of each concentration. The base portion (1.0$1.5 \mathrm{~cm}$ ) of cuttings were soaked carefully in solution for 5 seconds. Then these treated cuttings were planted into polythene sleeves containing prepared soil mixture as rooting media at evening.

The Randomized Block Design (RBD) was followed in the experiment in an arrangement with four replications having 20 cuttings in each replication under every treatments. The soil filled polythene sleeves with cuttings were lightly irrigated every day for first week of dibbling and then maintained one day interval for irrigation up to experimental period and besides this weeding was performed weekly. After 90 days of cuttings dibbling, various growth parameters were evaluated against the treatments. For that purpose, cuttings were carefully uprooted and medium particles adhered to roots were removed carefully by hand.

Data were collected on growth parameters i.e., rooted cutting, root number per cutting, length of root and shoot, survival rate of cutting and simple arithmetic calculation was performed to 
get consolidated figure on blocks and treatments for each parameters. The data were analyzed using General Linear Model of SPSS software (version 15) and analysis of variance (ANOVA) was performed to determine the effect of different concentration of IBA on dependent variables. Means on selected parameters were compared using Tukey's test at 5\% level of significance.

Rooting and survival percentage of cuttings were influenced significantly $(\mathrm{P}<0.05)$ by the application of IBA (Table 1). All treatments showed higher result over the control.

Rooting percentage of cuttings varied from $35.78 \%$ to $79.85 \%$ and the maximum $(79.85 \%)$ rooting was recorded when the cuttings were treated with $4000 \mathrm{ppm}$ IBA. Under treatment $\mathrm{T}_{3}$ which was statistically identical to that of $79.78 \%$ noted in treatment $\mathrm{T}_{4}$ at $6000 \mathrm{ppm} \mathrm{IBA.}$ The minimum rooting percentage of $35.78 \%$ was recorded in control.

Maximum survival rate of cuttings was recorded $57.60 \%$ in treatment $\mathrm{T}_{3}$ when the cuttings were treated with 4000 ppm IBA against minimum survival rate was $24.64 \%$ in control. Survival rate of cuttings was recorded $57.38 \%$ in treatment $\mathrm{T}_{4}$ which was identical with treatment $\mathrm{T}_{3}$. It was also observed that survival rate was strongly and positively correlated with rooting percentage (Figure 1).
Weaver (1972) stated that growth regulators changed the number and the type of root and IBA was a manufacturer of the strong fringe root. Khan et al. (1991) and Gyana (2006) also reported that treating cuttings with Indole Butyric Acid (IBA) increased the percentage of rooting, root initiation, root number and as well as uniformity of roots in Camelia sinensis.

Data presented in Table 1 showed that root number, root length and shoot length were influenced significantly $(\mathrm{P}<0.05)$ by the application of IBA. All treatments showed higher result over the control.

The root number per cutting ranged from 4.63 to 8.33 recorded in treatment $T_{1}$ and $T_{4}$ respectively which was gradual increase with the increased of IBA concentration. Maximum root number (8.33) was observed when the cuttings treated with $6000 \mathrm{ppm} \mathrm{IBA}$ in $_{4}$ which was statistically similar to the data of 8.23 noted in $\mathrm{T}_{3}$ at 4000 ppm IBA and the lowest root number (4.63) was observed in control.

The root length of the cutting was responded significantly to the treatments. The root length raged from $2.20 \mathrm{~cm}$ to $4.85 \mathrm{~cm}$ in different treatments. The maximum root length of $4.85 \mathrm{~cm}$ was observed in treatment $T_{3}$ at $4000 \mathrm{ppm}$ IBA which was statistically similar to that of $4.80 \mathrm{~cm}$ noted in treatment $\mathrm{T}_{4}$ at $6000 \mathrm{ppm} \mathrm{IBA}$ and both were significantly different to that of treatment $\mathrm{T}_{1}$ at $0 \mathrm{ppm} \mathrm{IBA}$ and $\mathrm{T}_{2}$ at2000 ppm IBA.

Table 1. Effect different IBA concentration on different parameters of tea cuttings establishment

\begin{tabular}{lccccc}
\hline $\begin{array}{l}\text { Treatments } \\
\text { (IBA doses) }\end{array}$ & $\begin{array}{c}\text { Survival rate } \\
(\%)\end{array}$ & $\begin{array}{c}\text { Root number } \\
\text { (unit/cutting) }\end{array}$ & $\begin{array}{c}\text { Root length } \\
(\mathrm{cm} .)\end{array}$ & $\begin{array}{c}\text { Shoot length } \\
(\mathrm{cm} .)\end{array}$ & $\begin{array}{c}\text { Rooting rate } \\
(\%)\end{array}$ \\
\hline $\mathrm{T}_{1}:$ Control & $24.64^{\mathrm{a}}$ & $4.63^{\mathrm{a}}$ & $2.20^{\mathrm{a}}$ & $5.43^{\mathrm{a}}$ & $35.78^{\mathrm{a}}$ \\
$\mathrm{T}_{2}: 2000 \mathrm{ppm}$ & $29.93^{\mathrm{b}}$ & $5.25^{\mathrm{b}}$ & $2.91^{\mathrm{b}}$ & $7.85^{\mathrm{b}}$ & $45.13^{\mathrm{b}}$ \\
$\mathrm{T}_{3}: 4000 \mathrm{ppm}$ & $57.60^{\mathrm{d}}$ & $8.23^{\mathrm{cd}}$ & $4.85^{\mathrm{d}}$ & $12.70^{\mathrm{cd}}$ & $79.85^{\mathrm{d}}$ \\
$\mathrm{T}_{4}: 6000 \mathrm{ppm}$ & $57.38^{\mathrm{cd}}$ & $8.33^{\mathrm{d}}$ & $4.80^{\mathrm{cd}}$ & $12.98^{\mathrm{d}}$ & $79.78^{\mathrm{cd}}$ \\
\hline
\end{tabular}

Means within a column followed by same letters are not significantly different at $5 \%$ level of significance according to Tukey's multiple range test. 


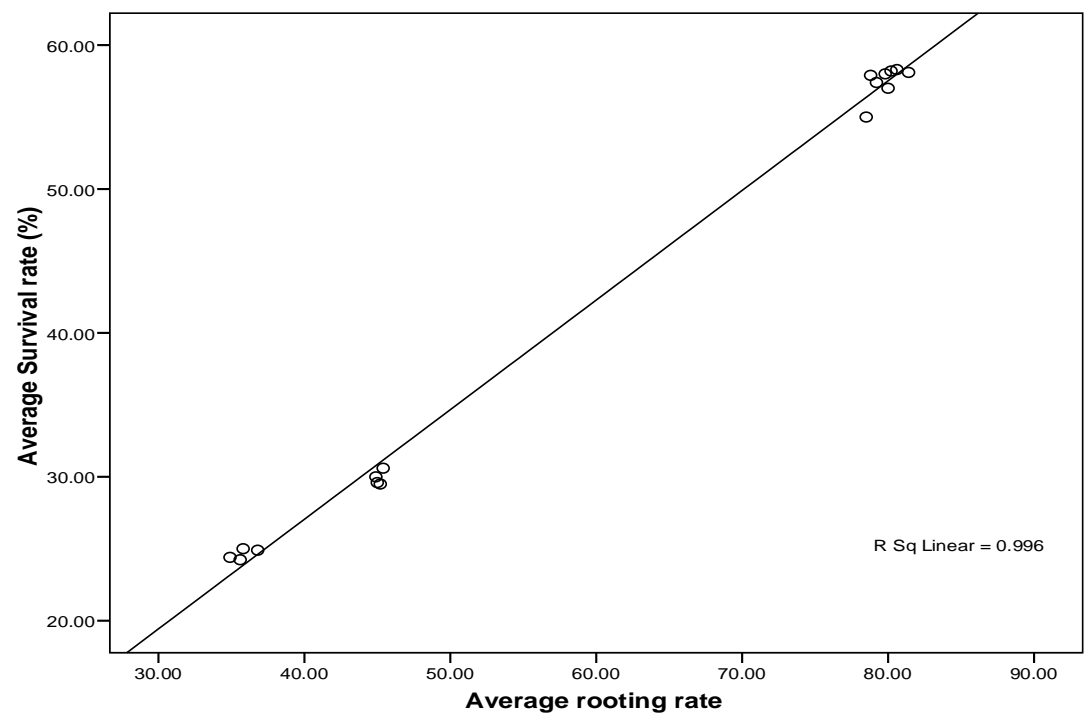

Figure 1. Relationship between rooting and survival rate of tea cutting of BT-2 variety

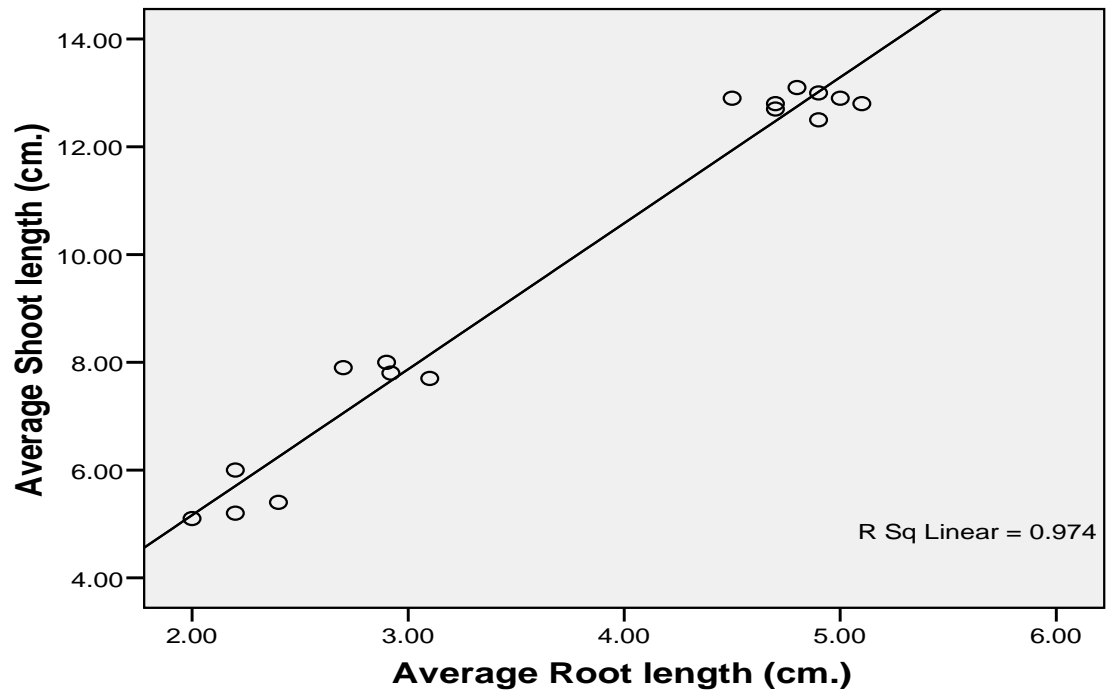

Figure 2. Relationship between root and shoot length of tea cutting of BT-2 variety 
The shoot length of the cutting was responded significantly to the different treatments and ranged from $5.43 \mathrm{~cm}$ to $12.98 \mathrm{~cm}$. The highest shoot length $12.98 \mathrm{~cm}$ was observed in $\mathrm{T}_{4}$ at 6000 ppm IBA followed by the shoot length $12.70 \mathrm{~cm} \mathrm{inT} \mathrm{T}_{3}$ at $4000 \mathrm{ppm} \mathrm{IBA}$ and both were statistically identical. The minimum shoot length $5.43 \mathrm{~cm}$ was obtained in control. It was observed that root and shoot length were increased progressively with the increase of IBA concentration. It was also observed that there was a strong and positively correlation between root length and shoot length (Figure 2).

According to Badshah et al. (2003), IBA alone can be used for single node cutting of tea plant as plant regulator and the experimental results of 8000 ppm IBA have significantly the best result with regard to root number (9.83) of tea cutting. Xian et al. (2008) mentioned that stem cuttings pretreated with indole-3-butyric acid (IBA) in quick-dip method got the best rooting traits (rooting $86.7 \%$, root number 23.1 and root length $6.4 \mathrm{~cm})$ in Paeonia cuttings. The supported findings were reported by Reddy et al.(2005) who found that maximum cumulative shoot length was recorded in application of auxin at 2000-2500 ppm in scented geranium (Pelargonium graveolens) cuttings and auxin cause increased linear growth of stem by way of cell elongation.

The results indicated that IBA treated cuttings demonstrated better results as compared to control in all agronomic parameters. The vegetative propagation of tea through stem cuttings with IBA treatment can be applied on commercial scale for rapid multiplication. IBA application in tea cutting at $4000 \mathrm{ppm}$ produced the highest rooting rate $(79.85 \%)$, survival rate $(57.60 \%)$ and root length $(4.85 \mathrm{~cm})$ and alsoat $6000 \mathrm{ppm}$ produced the highest root number per cutting (8.33) and highest shoot length (12.98 $\mathrm{cm})$. Results to the context ofall parameters of tea cutting establishment were found statistically similar in case of 4000 ppm and 6000 ppm IBA concentration. Hence from the results, it can be inferred that IBA had a positive effect on the establishment of stem cuttings of tea (BT-2 variety) and $4000 \mathrm{ppm}$ IBA can be applied for raising better plants from stem cuttings in the tea nursery.

Abou-Rawash, M., El-Wakeel, H. F.Kaseem, N. and. Mohamed, E.A. 1998. Studies on the vegetative propagation of some citrus rootstocks. Annals of Agricultural Sciences, Cairo, 43: 523-537.

Badshah, N.,Qasim and Tehseenullah, M. 2003. Response of single node cutting of tea plant to plant growth regulators application. Sarhad Journal of Agriculture, 18(4): 371-374.

DPP (Development Project Proposal) on Extension of small holding tea cultivation in Chittagong Hill Tracts, Bangladesh Tea Board, 2016. 9 pp.

Gyana, R. R. 2006. Effect of auxins on adventitious root development from single node cuttings of Camelia sinensis (L.) and associated biochemical changes. Plant Growth Regulation, 48: 111-117.

Khan, A. R., Ahmud, N and Hamid, F.S. 1991. Effect of growth regulating substances on the rooting of tea Camellia sinensis 1. cutting. Sarhad Journal of Agriculture, 7(2): $1-5$.

PMTC (Project Management and Training Consultant) International Limited, 2002. Report on comprehensive feasibility study for small holding tea plantation in Chittagong, Chittagong Hill Tracts, Sylhet and Northern Bangladesh, February, 2002. Dhaka. 96 pp.

Prockter, N. J. 1975. Simple Propagation. 3rd Edition. Faber and Faber ltd, London, UK. $246 \mathrm{pp}$.

Reddy, P. C. H., Chandrasekhar, R., Reddy, Y. N. and Rajkumar, M. 2005. Effect of growth regulators on rooting of Scented geranium (Pelargonium graveolens) 
cuttings. The Journal of Research ANGRAU, 33(4): 114- 116.

Venkataramani, K. S. 1958. Report of the Botanist for 1958 A.R. UPASAI. Sci. Dep. Tea. Sect, 114- 115 pp.

Weaver R.J. 1972. Plant Growth Substances in Agriculture. W.H. Freeman and Company, San Frasisco. 127 pp.
Xian, F. G., Xiling, F., Dekui, Z. and Yan, M. 2008. Effect of auxin treatments, cuttings collection date and initial characteristics on Paeonia 'Yang Fei Chu Yu' cutting propagation. Scientia Horticulturae, 119: 177-181. 